\title{
The role of real estate and gold as inflation hedges: the Islamic influence
}

Role of real estate and gold as inflation hedges

\author{
Osman Gulseven
}

Department of Economics, Middle East Technical University, Ankara, Turkey and School of Business, Skyline University College, Sharjah, United Arab Emirates, and

\author{
Ozgun Ekici \\ Department of Economics, Ozyegin Universitesi, Istanbul, Turkey
}

\begin{abstract}
Purpose - This paper aims to understand how aversion to interest income in Islam may influence the demand for real estate and gold when inflation is rampant.

Design/methodology/approach - According to Markowitz's mean-variance model, an optimal portfolio is one that blends maximum return with minimum variance. In investment portfolios, real estate and gold serve as inflation hedges. For religious reasons, many Muslims exclude interest-earning assets from their portfolios, however. This paper explores how this attitude influences the hedging role of real estate and gold when inflation is rampant. This paper compares optimal portfolios that include and do not include interestearning assets. In the calculations, this study uses monthly Turkish data from 1997 until 2018.

Findings - The analysis shows that the best hedging instrument against inflation is an interest-earning asset. In its absence, the role of real estate and gold as inflation hedges markedly increases: For a mediumreturn and medium-risk portfolio, for instance, the portfolio share of gold holdings increases from $3.16 \%$ to $58.43 \%$ and that for real estate increases from $14.97 \%$ to $24.06 \%$.

Originality/value - This paper is a pioneering work on the influence of Islam on the roles of real estate and gold as inflation hedges when inflation is rampant. It provides an explanation from financial theory for the strong real estate and gold demand in Turkey in the past two decades.
\end{abstract}

Keywords Islamic finance, Portfolio optimization, Interest-Riba, Real Estate Market, Gold and Silver, Inflation and Indexation

Paper type Research paper

\section{Introduction}

According to modern portfolio theory, pioneered by Markowitz (1952), risk-averse investors choose investment portfolios by balancing out expected return and risk. Two asset classes are of utmost importance in investment portfolios real estate and gold. Real estate is by far the most significant store of household wealth in the world. As for gold, as of 2017, the total amount of it ever mined is over 190,040 tons, according to the World Gold Council. The worth of this gold is a stunning 11.4 trillion dollars (valued at $\$ 60$ per gram).

Many prior research studies studied the roles played by real estate and gold in optimal investment portfolios (Section 2). One particular theme stands out in these studies: their role as inflation hedging instruments. Our paper also contributes to this literature: we study a country, Turkey, which has a history of high and volatile rates of inflation. We observe that

JEL classification - G11, G18
Received 31 January 2019 Revised 29 August 2019 10 January 2020 8 September 2020 Accepted 15 October 2020 
IMEFM

14,2

\section{2}

Figure 1.

The monthly new housing sales in Turkey in recent years, the household demand for real estate and gold in Turkey has been extremely strong, more so than what can be justified by ordinary market forces. We propose a cultural explanation for this phenomenon.

Under rampant inflation, the instrument that best serves as an inflation hedge is an interest-earning asset. However, in Turkey, many people deem interest income un-Islamic, and they avoid investing their savings in interest-earning assets. We find evidence from modern portfolio theory that this situation may have had a marked influence on the prominence of real estate and gold in their investment portfolios. Absent an interest-earning asset, real estate and gold may have played a greater role as inflation hedges, fueling the household demand for real estate and gold in the country.

Turkey suffered under rampant inflation for decades. In the 1980s and 1990s, the rate of inflation (as calculated by CPI) ranged from $30 \%$ up to $110 \%$. In the 2000 s, inflation was tamed, and in 2009 its rate reached as low as $6.3 \%$. However, in recent years, the rate of inflation soared up again and reached above $25 \%$. Given its historically high and volatile rates, inflation can be singled out as the primary concern for Turkish households when forming their investment portfolios.

To shield savings from high and volatile inflation, Turkish households invest in a variety of assets, including equity and fixed-income instruments. By global standards, however, household demand for equity and fixed-income instruments is low in Turkey. Although the country's share in global GDP is around $1 \%$, its share is much lower in global equity and bond markets. According to World Federation of Exchanges, in 2017, Turkey's Borsa Istanbul's share in global equity markets was $0.27 \%$ (worth $\$ 228 \mathrm{bn}$ out of $\$ 85 \mathrm{tn}$ globally) and Turkey's share in global markets for fixed-income instruments was $0.26 \%$ (worth $\$ 279 \mathrm{bn}$ out of $\$ 108 \mathrm{tn}$ globally). Even these low figures overstate the low appeal of equity and fixed-income instruments for Turkish households. In Turkey, bonds are held mostly by banks rather than households. Then, in the stock market, around two-thirds of the shares exchanged are held by foreigners. Strikingly, in place of stocks and bonds, Turkish households turned to in recent years two investment instruments in particular, real estate and gold.

Figure 1 below shows the monthly figures for brand new housing sales in Turkey in recent years. The sales averaged at 50,000 per month or 600,000 per annum. However, in the same period, Turkey's annual population increase was only 800,000. According to the

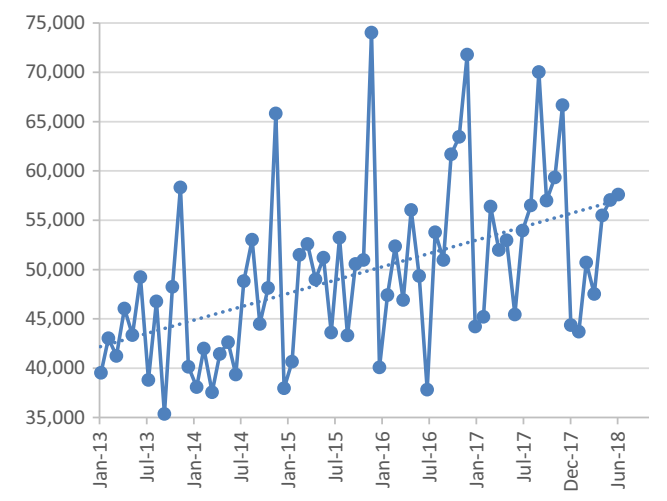

Source: TUIK housing sales data 
United Nations Economic Commission for Europe, in 2017, the share in GDP of the construction industry was $9.7 \%$ in Turkey. With this ratio, Turkey ranked 3rd out of 44 countries in Europe. The strong demand for real estate in the country is beyond what can be justified by ordinary market forces. The country's construction sector is often said to be "bloated" or "oversized."

Figure 2 below shows the demand for gold in Turkey in recent years. The gold demand has been strong for both jewelry and investment (gold bars and coins). In this period, the country's share in global household gold demand was 3\%, three times its share in global GDP. In 2017, with a per capita gold demand of 1.2 grams, Turkey ranked 8th in the world. All seven countries that surpassed Turkey (Hong Kong, Switzerland, UAE, Kuwait and Singapore, Saudi Arabia and Germany) had much higher per capita incomes than Turkey. According to a World Gold Council estimate in 2013, the amount of gold tucked "under the pillow" by Turkish households stood at 3,500 tons (44 grams per person).

Many view the strong real estate and gold demand in Turkey as worrisome. According to IMF figures, among the emerging market and developing economies, Turkey has one of the lowest gross national savings rates, which ranged from $12 \%$ up to $17 \%$ in the years since 2000. This low savings rate also manifests itself as chronic deficits in the current account. It is not uncommon that a shortage in foreign funding leads to an exchange rate crisis and an abrupt depreciation of the Turkish Lira. Therefore, to foster growth, the country's limited savings must be channeled into productive uses. However, the strong appetite of Turkish households for real estate and gold is not helpful. Real estate cannot be exported and gold is an imported asset for Turkey. Therefore, investment in real estate and gold steals much-needed funds away from more productive investment projects, such as in growth-enhancing export-oriented industries.

In this paper, we propose an explanation for the strong real estate and gold demand in Turkey. Our explanation is rooted in two influences: Islam and Turkey's historically high and volatile rates of inflation.

By Western standards, Turkey is a deeply religious society. According to a widely quoted figure, $98 \%$ of Turks are Muslims. Islam's influence runs deep and influences

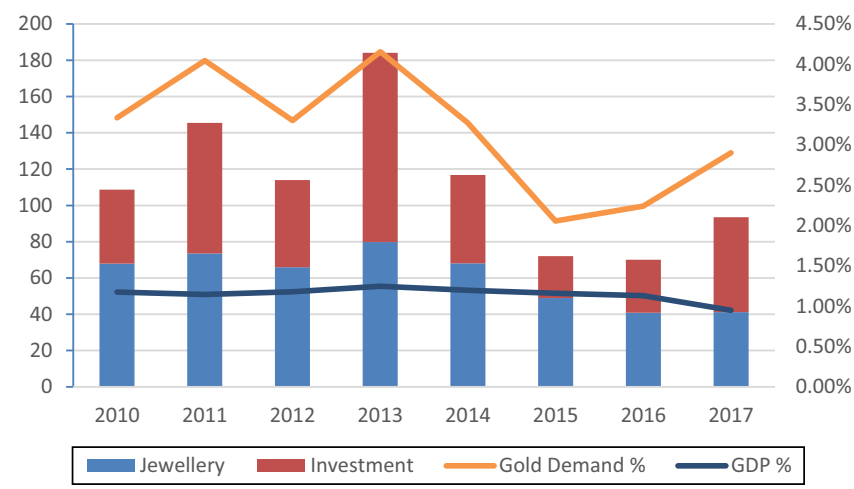

Source: World Gold Council Gold Demand Trends Data. The left axis shows the amount of gold demanded in Turkey (measured in tons). The right side shows the country's share of global gold demand
Role of real estate and gold as inflation hedges

393

393


IMEFM

14,2

\section{4}

people's everyday practices. According to Konda Araştırma ve Danışmanlık (2018): in Turkey, $70 \%$ of people view themselves as traditional or religious conservatives; $79 \%$ do not use alcohol; [1] 65\% fast regularly during the Islamic holy month of Ramadan; $43 \%$ perform their daily prayers regularly and $63 \%$ of women use various styles of head coverings. Islam also influences people's investment choices. Many Turks deem it unIslamic to earn interest on money. In a survey study by Konda Araştırma ve Danışmanlık (2007), $52.7 \%$ of Turkish people said that they find it wrong to earn interest income on bank deposits.

The belief that interest income is un-Islamic is rooted in several verses in the Qur'an (3:130, 4:161, 30:39, 2:275-2:280). In these verses, riba is mentioned and condemned, which can roughly be translated from Arabic as "usury" or "unjust, exploitative gains made in trade or business." There is no universal agreement among Islamic scholars as to what this term corresponds to in real-life business practice. However, the majority deems interest charged on loans as riba and hence call it un-Islamic. We refrain from a theological discussion here. However, we should note that in Turkey, for religious reasons, many people refuse to invest their savings in fixed-income instruments. However, when inflation is high and volatile as in Turkey, the instrument that best serves as an inflation hedge is an interestearning asset. When it is not a viable option, other instruments, such as real estate and gold, may well play a more prominent role in investment portfolios. Therefore, we hypothesize that in Turkey, it may be the aversion to interest income, combined with the influence of high and volatile inflation, which fueled household demand for real estate and gold.

To test our hypothesis, we resort to Markowitz's mean-variance model. We calculate optimal investment portfolios. In our calculations, we use monthly return data from January 1997 until June 2018. The assets considered are those most held by Turkish households: real estate, gold, stocks, foreign currency (USD and euro) and interest-earning deposits. We calculate optimal portfolios under two scenarios: when the portfolio includes all these instruments, and when interest-earning deposits are excluded. We compare our findings and check how the exclusion of interest-earning deposits influences the demand for real estate and gold. As a robustness check, we repeat our analysis using four sets of data: (i, ii) nominal and real arithmetic mean returns on assets; and (iii, iv) nominal and real geometric mean returns on assets. In all cases, the results confirm our hypothesis: In optimal portfolios, the exclusion of interest-earning deposits leads to a substantial rise in portfolio real estate and gold holdings. For instance, when we carry out our calculations using real geometric mean returns, for a medium-return and medium-risk portfolio, the rise is from $14.97 \%$ to $24.06 \%$ for portfolio real estate holdings and from $3.16 \%$ to $58.43 \%$ for portfolio gold holdings.

One may argue that Turkey's strong demand for gold has been for its role as an inflation hedge alone and that people's religious sensitivities played no part in it. However, there is evidence to believe otherwise. First, in Turkey, gold is not an excellent hedging instrument against inflation: The correlation of the return on gold and the rate of inflation is only 0.31 (Table 2). Second, the demand for gold is not as strong in other high-inflation countries: in the period of our analysis, in some countries (e.g. Venezuela, Argentina and Ukraine), inflation was higher and more volatile than in Turkey. However, none experienced nearly as strong a demand for gold as Turkey. Therefore, there is evidence to believe that religious influence is real. Most likely, the Islamic influence amplified the role as an inflation hedge of gold and spurred its demand in Turkey.

We should also note a limitation of our analysis. In our paper, we do not perform a causality analysis and identify a direct relationship between religiosity and people's investment choices. That would require suitable data at the individual level, but we do not have it. In future studies, it will be useful for hypothesis is tested, and a more direct 
relationship is found between religiosity and people's investment choices, using a causality analysis and using individual-level data.

Our findings have important policy implications. In Turkey, the fact that conservative investors refrain from interest income, combined with rampant inflation, fuels household demand for real estate and gold. This situation worsens the country's balance of trade and diverts much-needed funds away from growth-fostering industries. To tame this effect, the rate of inflation must be lowered and stabilized. Furthermore, to draw savings of conservative households into the financial system, new investment instruments can be introduced and popularized, that appeals to these households. At present, there are indeed six Islamic banks in Turkey. (Islamic banks are called "participation banks" in Turkey.) However, many conservatives are suspicious of the compliance of their services with Islamic tenets, and the share of Islamic banks in the banking industry is still small. Learning from the experiences of countries with larger Islamic banking industries (for instance, the United Arab Emirates and Malaysia) can guide policymakers.

The rest of the paper is organized as follows: Section 2 discusses the relevant literature. Section 3 explains our data. Section 4 introduces our empirical model. Section 5 presents our results. Section 6 gives a summary of our findings. Section 7 concludes with policy recommendations.

\section{Literature review}

There is a rich literature on optimal portfolio analysis. In this review, we restrict attention to prior work relevant to our research's main ingredients:

- The role as an inflation hedge of different assets.

- The influence of Islam on people's investment behavior.

- And prior studies on household investment behavior in Turkey.

There are different ways to define an inflation hedge (Bodie, 1976). For our purposes, an inflation hedge is an instrument which, if added to an investment portfolio, reduces the variation of the portfolio return but not the expected return. Assets with this property must have a positive and strong correlation with the rate of inflation. In the literature, many assets have been considered for their inflation hedging properties. For an excellent survey on the subject, see Arnold and Auer (2015).

About the inflation-hedging effectiveness of interest-earning assets, the study by Fisher (1930) had been of great influence. He argued that the nominal interest rate should be equal to the sum of the inflation rate and the expected real return. However, Fama and Schwert (1977) find that the US Government bills and bonds are a complete hedge only against expected inflation. Bekaert and Wang (2010) make the same point, stating that bonds fail to hedge unexpected inflation. Amenc et al. (2009) show that if short-term liability risk hedging is the sole focus, the optimal asset allocation consists of investing 100\% into an inflationindexed bond. For other studies on inflation-linked bonds, see Swinkels (2012) and Kothari and Shanken (2004).

Lintner (1975) points out that in theory, stocks should serve well as inflation hedges, as they represent claims against real assets, whose values should keep pace with changes in purchasing power. However, in a seminal study, using the New York Stock Exchange (NYSE) equity returns, Bodie (1976) finds that equities appear to be a perverse inflation hedge. Therefore, for inflation hedging, an investor must sell stocks short. There are other contemporary studies supporting this puzzling result; see, for instance, Nelson (1976), Jaffe and Mandelker (1976), Fama and Schwert (1977), Gultekin (1983). Fama (1981) explains this
Role of real estate and gold as inflation hedges

395 
IMEFM

14,2

puzzle with a proxy hypothesis: that inflation is indeed a proxy for real economic trends and that the negative relationship between inflation and stock returns is a spurious one. Geske and Roll (1983) and Kaul (1987) also argued that the negative relationship is a spurious one, albeit they provided different explanations. However, these early empirical findings suffer from small samples. Also, the Fisher effect describes a long-run phenomenon, but these earlier studies worked with short-run data. More recent research addresses these and some other issues and their findings present a more diverse picture: Luintel and Paudyal (2006), using UK data, finds that stocks serve as inflation hedges. Alagidede and Panagiotidis (2010), studying African stock markets, find that the stock market tends to provide a hedge against rising consumer prices. Kim and Ryoo (2011) find strong evidence that USA common stocks have been a hedge against inflation in the long run. Ahmed and Cardinale (2005), studying large economies in the world and considering both the long term and the short term, obtain mixed results.

Arguably, stable currencies such as the USD and euro are part of the money demand, and they should not be considered as investment instruments. However, in inflation-torn countries, investing in foreign currency is commonplace (as in Turkey). Fischer (1982) mentions that in countries where inflation runs high, people carry stable foreign currencies. Vieira et al. (2012) suggest that the reason for persistent foreign currency demand in a country is the high level of domestic debt and the default risk of the country. Stix (2013) finds that a lack of trust in banks, memories of past banking crises and weak tax enforcement are essential factors in explaining why many households hold a significant portion of their assets in the form of stable currencies.

Gold is another form of investment to hedge against inflation. Larsen and Mcqueen (1995) suggest that gold performs well as an inflation hedge, but gold stocks do not provide the same function. Batten $e$ al. (2014) find a strong positive relationship between the price of gold and inflation. Baur and McDermott (2010) find that, in the face of extreme adverse market shocks, gold helps reduce losses and hence acts as a stabilizing force for the financial system. Wen and Cheng (2018) argue that in emerging markets gold acts as a safe asset. Bruno and Chincarini (2010) find that the optimal share in investment portfolios of portfolio gold holdings is less than $10 \%$. For two other related studies, see Beckmann and Czudaj (2013) and Reboredo and Rivera-Castro (2014).

Another asset class known for its hedging function against inflation is real estate. Barry and Rodriguez (2004) analyze the risk and return properties of real estate in emerging markets. Hasanov and Dacy (2009) find that the real returns on residential property are positive and not very volatile, and therefore, residential property acts as an inflation hedge. Christou et al. (2018) find that housing prices offer a hedge against a non-housing consumer price index in the USA. In another related study, Caporale and Sousa (2016) analyze the relationship between equity and housing returns in emerging markets, and they argue that real estate is an excellent instrument to diversify a portfolio of stocks. Arnold and Auer (2015) state that among commons stocks, gold, fixed-income securities and real estate, there is no scientific consensus as to which asset class performs best as an inflation hedge.

In Muslim-majority countries, the role of interest is highly controversial. Several verses in the Qur'an (3:130, 4:161, 30:39, 2:275-2:280) mention riba and condemn it. This term literally means "excess" or "increase". The mainstream Islamic view is that interest charged on loans is riba, and it is not permissible in Islam. It is this taboo that gave birth to and caused the proliferation of the so-called "Islamic banking" system. Underlying Islamic banking practices is the dedication that all forms of payment and receipt of interest should be eliminated. 
Islamic banks offer investors profit-and-loss-sharing arrangements. Under a profit-andloss-sharing arrangement, the bank does not offer a fixed interest rate. Instead, using financing obtained from depositors, the bank funds businesses or people under Islamic guidelines. Then as the funds are repaid, the bank pays depositors a percentage of the profits (or losses). Underlying the Islamic financing practices are the methods of trustee finance (mudaraba), equity participation (musharaka) and "mark-up." Prophet Muhammad himself employed the mudaraba principle when he acted as the agent (mudarib) for his wife Khadija. For two extensive resources on Islamic banking practices, and the role of interest in Islam, see Lewis and Algaoud (2001) and Hassan and Lewis (2009).

But many people consider Islamic banking practices meeting the letter of Islamic law but violating its spirit. Chong and Liu (2009) argue that, in essence, the profit-and-loss-sharing paradigm is nothing different than conventional banking practice. Khan (2010) argues that Islamic banking is simply a rebranding of everyday banking practices. Azad et al. (2018) argue that arbitrage opportunities force the returns on the so-called profit-and-loss-sharing arrangements to converge with global interest-rate benchmarks. For a discussion of the divergent positions taken by traditionalists and modernists on the definition of riba, see Algaoud and Lewis (2007).

There are also research studies on household investment behavior in Turkey. Gülseven and Ekici (2016) note that in Turkey, a major concern of Turkish households in their investments is shielding their savings from inflationary depreciation and volatility. Soytas et al. (2009) argue that in Turkey, gold is considered a safe-haven asset. Tursoy and Faisal (2018) find that in Turkey, the relationship between gold prices and the stock market is negative. Aktürk (2016) finds that in Turkey, the stock returns are positively related to $e x$ ante inflation expectations, and they are negatively related to ex-post inflation realizations. Ozkan et al. (2012) identify direct causality effects between the real estate sector and the Turkish GDP. Ceritoğlu (2017) finds that in Turkey, an increase in real estate prices leads to a rise in consumption. Gulseven (2018) notes the importance of demographic factors as an influence on household behavior.

\section{Data}

\subsection{Data source}

In our study, we use monthly return data for the following assets: interest-earning deposits, stock market, foreign currency (USD and euro) and gold. The data is obtained from the Turkish State Statistics Institute (TUIK). Since TUIK's data is available since January 1997, our analysis covers the period from January 1997 until June 2018. As a measure of inflation, we use the change in consumer price index (CPI), which is also provided by TUIK.

The return on interest-earning deposits is the average monthly interest rate of the $11 \mathrm{big}$ banks in Turkey. The return on the stock market is as measured by Turkey's main stock index, BIST100. We also include in our analysis the two most widely held foreign currencies in Turkey: USD and euro. Since euro came into existence in January 2002, as a substitute for its returns in the pre-2002 period, we use the return data for Deutsche Mark.

TUIK's database does not include data on real estate returns. For that purpose, we use the hedonic housing price index (HHPI) provided by the Central Bank of the Republic of Turkey. Controlling for the quality effects, the HHPI index measures the change in housing prices in Turkey. Unfortunately, this index is relatively new and available only since 2010. Therefore, for the pre-2010 period, as a substitute, we use TUIK's real estate PPI. We calculated the correlation between these two indices for the post-2002 period. The correlation is 0.966, which hints that the use of real estate PPI as a substitute is a safe practice. 
IMEFM

14,2

398

\subsection{Nominal vs real returns}

We carry out our analysis using both nominal and real returns: Let $X_{t}$ be an asset's price at the end of period $t$. Let $\pi_{t}$ be the rate of inflation at period $t$. The asset's nominal and real (rates of) returns at period $t, R_{t}(X)$ and $r_{t}(X)$, are calculated as follows:

$$
\begin{aligned}
& R_{t}(X)=\frac{X_{t}-X_{t-1}}{X_{t-1}} \\
& r_{t}(X)=\frac{1+R_{t}(X)}{1+\pi_{t}}-1
\end{aligned}
$$

\subsection{Arithmetic vs geometric mean returns}

The arithmetic mean return is the sum of the monthly returns divided by the number of observations. It measures the expected return on a single period. However, the arithmetic mean return does not account for the long-term effects of compounding if the series exhibit serial correlation. Therefore, for a forward-looking investor who holds assets longer than one month, the geometric mean return is probably a better measure of expected return. Consequently, we carry out our analysis using both arithmetic and geometric mean returns.

Let $R_{t}(X)$ be an asset's nominal return at period $t$. Then, over $n$ periods, the nominal arithmetic and geometric mean returns are calculated as follows:

$$
\begin{aligned}
& \text { Arithmetic Mean Return }(X)=\frac{\sum_{t=1}^{n} R_{t}(X)}{n} \\
& \text { Geometric Mean Return }(X)=\left(\prod_{t=1}^{n}\left(1+R_{t}(x)\right)\right)^{1 / n}-1
\end{aligned}
$$

The real arithmetic and geometric mean returns are calculated similarly.

\subsection{Summary statistics}

Table 1 below presents the summary statistics on asset returns and the CPI-rate of inflation.

Table 1 shows that Turkey suffered under rampant inflation in the past two decades. From January 1997 and June 2018, the average monthly inflation rate was 1.68\% (about $20 \%$ annually). Consequently, over this period, the USD and the euro appreciated substantially against the Turkish Lira. Turks often hold these currencies since they are stable currencies, and they do not fast depreciate as the Turkish Lira. Nonetheless, considered as assets, they are not great investment instruments. In the period of our analysis, their values depreciated in real terms, and they performed worse than other investment instruments.

Based on arithmetic mean returns, the best-performing asset was BIST100 (2.35\%). It is followed by interest-earning deposits $(2.19 \%)$ and gold $(2.07 \%)$. However, the periodic returns on BIST100 are very volatile and exhibit serial correlation. Therefore, based on geometric mean returns, interest-earning deposits $(2.17 \%)$ and gold $(1.95 \%)$ outperformed BIST100 (1.85\%). Also, note that the mean return on real estate was almost the same as the rate of inflation.

Figure 3 below presents the nominal growth of 100 Turkish Liras invested in various assets. For comparison, the figure also shows the growth of the CPI index over this period. 
Figure 4 below presents the real growth of 100 Turkish Liras invested in various assets. For comparison, the figure also shows the real growth in the CPI index as a straight line.

It is clear from Figure 4 that the most volatile investment instrument was BIST100. In the figure, the sharp declines in the stock index in the financial crisis years (1999, 2003 and 2008) are also noticeable. Also, note that gold performed poorly until 2008, but since then, it has become a lucrative investment. In most years, the real returns on foreign currencies were negative. The return on real estate moved almost parallel to inflation. Overall, the return on interest-earning deposits was quite high. However, also note that since 2009, the real return on interest-earning deposits was close to zero. Table 2 below presents in the matrix form the correlations of the nominal and real returns on assets.

The two correlation matrices are fairly similar. The returns on gold and the two foreign currencies are strongly correlated. Strikingly, the real return on BIST100 is negatively correlated with the real returns on all other assets, in particular, for gold and the two foreign currencies. This situation is a clear reflection of the influence of capital flows in and out of Turkey: when there is a capital inflow, Turkish assets become more valuable. The stock index increases and the Turkish Lira appreciates vis-à-vis foreign currencies and gold. Easier access to foreign funds also drives down the real interest rate. When there is a capital outflow, the opposite happens.

\begin{tabular}{lccrrrrr}
\hline Monthly return & Arithmetic mean & Geometric mean & SD & CV & Minimum & Median & Maximum \\
\hline Nominal interest & 2.19 & 2.17 & 1.93 & 0.88 & 0.48 & 1.36 & 6.30 \\
Nominal Bist100 & 2.35 & 1.85 & 10.39 & 4.76 & -30.80 & 1.63 & 53.40 \\
Nominal USD & 1.57 & 1.49 & 4.37 & 2.78 & -8.50 & 1.24 & 30.90 \\
Nominal euro & 1.52 & 1.43 & 4.22 & 2.77 & -7.70 & 1.07 & 28.90 \\
Nominal gold & 2.07 & 1.95 & 5.21 & 2.51 & -12.30 & 1.62 & 35.10 \\
Nominal real estate & 1.65 & 1.63 & 1.65 & 1.00 & -2.61 & 1.12 & 7.06 \\
Real interest & 0.50 & 0.49 & 1.12 & 2.24 & -3.80 & 0.39 & 3.40 \\
Real Bist100 & 0.65 & 0.18 & 9.81 & 15.07 & -35.17 & 0.54 & 44.90 \\
Real USD & -0.11 & -0.18 & 3.83 & -36.35 & -10.85 & -0.46 & 23.39 \\
Real euro & -0.16 & -0.23 & 3.76 & -23.94 & -12.18 & -0.55 & 21.50 \\
Real gold & 0.39 & 0.28 & 4.84 & 12.36 & -12.09 & -0.10 & 27.35 \\
Real estate & -0.02 & -0.03 & 1.36 & -67.41 & -4.56 & 0.11 & 4.02 \\
CPI index & 1.68 & 1.66 & 1.92 & 1.14 & -1.43 & 1.02 & 10.29 \\
\hline
\end{tabular}

Role of real estate and gold as inflation hedges

399

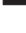


IMEFM

14,2

Figure 4 .

The real growth of 100 TL investment based on monthly real returns
It is important to note that vis-à-vis the CPI-rate of inflation, the correlation is highest for the interest rate (0.82). This means that at times of upward movements in the rate of inflation, the interest rates increased proportionately and protected savings from the adverse effects of the volatility in the CPI-rate of inflation.

\section{The model}

In our analysis, we use Markowitz's mean-variance model. In this model, it is assumed that risk-averse investors aim to maximize the expected return on their portfolios while minimizing the risk. In other words, investors want high expected returns and low volatility, and they choose their portfolios by balancing out these two wishes. A multitude of variations of this model has been used in the literature; see Callot et al. (2017), Loistl (2015), Loughran and Ritter (2002) and Zhang et al. (2017). We use the standard version here, in which the measure of risk is the variance.

Let $P$ be a portfolio consisting of $n$ assets: $X_{1}, X_{2}, \cdots, X_{n}$. Let $w_{i}$ be the weighting factor for asset $X_{i}$ at $P$. (That is, $w_{i}$ is the ratio of the savings invested in asset $X_{i}$.) Let $r_{i}$ be the expected return for asset $X_{i}$. The portfolio expected return, $r_{P}$, is calculated as follows:

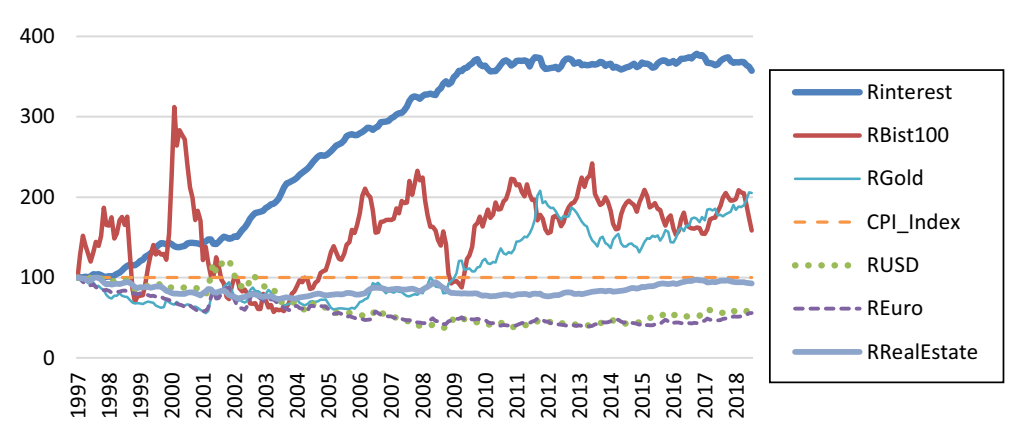

\begin{tabular}{lcccccc}
\hline Nominal returns & Ninterest & NBist100 & NUSD & NEURO & NRealEstate & NGold \\
\hline Ninterest & 1.00 & & & & & \\
NBist100 & 0.18 & 1.00 & & & & \\
NUSD & 0.35 & -0.22 & 1.00 & & & \\
NEuro & 0.34 & -0.26 & 0.84 & 1.00 & & \\
NRealEstate & 0.78 & 0.16 & 0.37 & 0.38 & 1.00 & 1.00 \\
NGold & 0.23 & -0.23 & 0.67 & 0.69 & 0.25 & RGold \\
CPI index & 0.82 & 0.22 & 0.43 & 0.41 & & \\
Real returns & Rinterest & RBist100 & RUSD & REURO & RRealEstate & \\
Rinterest & 1.00 & & & & & \\
RBist100 & -0.01 & 1.00 & & & & \\
RUSD & -0.01 & -0.37 & 1.00 & & & \\
REuro & 0.04 & -0.39 & 0.80 & 1.00 & & \\
RRealEstate & 0.56 & -0.02 & 0.10 & 0.15 & & \\
RGold & -0.02 & -0.33 & 0.61 & 0.65 & & \\
Note: All statistics are significant at $1 \%$ level & & & &
\end{tabular}

Table 2.

The correlation matrix for monthly nominal and real returns on assets

.




$$
r_{P}=\sum_{i=1}^{n} w_{i} r_{i}
$$

Let $\sigma_{i j}$ denote the covariance of the returns on assets $X_{i}$ and $X_{j}$. Let $\sigma_{P}$ be the variance of the portfolio return. The variance $\sigma_{P}$ is calculated as follows:

$$
\sigma_{P}=\sum_{i=1}^{n} \sum_{j=1}^{n} w_{i} w_{j} \sigma_{i j}
$$

Let $r_{0}$ be the portfolio expected return. The optimization problem solved by an investor is as follows:

$$
\begin{gathered}
\min _{\left\{w_{i}\right\}_{i=1}^{n}} \sum_{i=1}^{n} \sum_{j=1}^{n} w_{i} w_{j} \sigma_{i j} \\
\text { subject to } \\
\sum_{i=1}^{n} w_{i} r_{i} \geq r_{0} \\
\sum_{i=1}^{n} w_{i}=1 \\
w_{1}, \cdots, w_{n} \geq 0
\end{gathered}
$$

Above, equation (1) stipulates that the portfolio expected return will be at least $r_{0}$. Equation (2) stipulates that the sum of the weighting factors will be equal to 1 . Then the set of equation (3) stipulates that the weighting factors be non-negative (i.e. there is no short selling). Note that, for each choice of $r_{0}$, a set of weighting factors $\left\{w_{i}\right\}_{i=1}^{n}$, which solves the above problem, defines an optimal portfolio.

Markowitz's mean-variance model is the gold standard in the literature. In its original version, in calculations, the theory suggests the use of the arithmetic mean returns. However, arithmetic mean returns reflect expected returns for a single period. Arguably, for longer-term analysis, the use of geometric mean returns is more suitable. For an excellent discussion on the subject, see Estrada (2010). In empirical studies, for single-term analyses, arithmetic mean returns are used, but for longer-term analyses, the use of geometric mean returns is commonplace. To be on the safe side, we carry out our analysis using both arithmetic and geometric mean returns.

\section{Results}

The results of our analysis are given in Tables 3, 4, 5, 6 and in Figures 5, 6. The tables present optimal portfolio compositions. The figures show the efficient frontiers (the collections of optimal portfolios). On the diagrams, the x-axis indicates the portfolio standard deviation and the $y$-axis indicates the portfolio expected return.

We calculated optimal portfolios using four sets of data: (i, ii) nominal and real arithmetic mean returns(in Section 5.1; Tables 3, 4 and Figure 5); (iii, iv) nominal and real geometric mean returns (in Section 5.2; Tables 5, 6 and Figure 6). Therefore, we carry out our calculations four times. Then, in each of these four cases, in line with our purpose, we calculate optimal portfolios twice: once, when the portfolio includes interest-earning deposits and once when it does not. 


\section{IMEFM \\ 14,2}

Weighting factors

Portfolio's

Portfolios Ninterest NBist100 NUSD NEuro NRealEstate NGold Expected return SD

\begin{tabular}{|c|c|c|c|c|c|c|c|c|c|}
\hline \multirow{5}{*}{402} & \multicolumn{9}{|c|}{ Interest-earning deposits included } \\
\hline & A & $83.30 \%$ & $1.08 \%$ & $0.00 \%$ & $0.00 \%$ & $10.80 \%$ & $4.82 \%$ & $2.12 \%$ & $1.85 \%$ \\
\hline & B & $91.51 \%$ & $8.49 \%$ & $0.00 \%$ & $0.00 \%$ & $0.00 \%$ & $0.00 \%$ & $2.20 \%$ & $2.11 \%$ \\
\hline & $\mathrm{C}$ & $45.75 \%$ & $54.25 \%$ & $0.00 \%$ & $0.00 \%$ & $0.00 \%$ & $0.00 \%$ & $2.27 \%$ & $5.86 \%$ \\
\hline & $\mathrm{D}$ & $0.00 \%$ & $100.00 \%$ & $0.00 \%$ & $0.00 \%$ & $0.00 \%$ & $0.00 \%$ & $2.35 \%$ & $10.39 \%$ \\
\hline & Range & $0-92 \%$ & $1-100 \%$ & $0-0 \%$ & $0-0 \%$ & $0-11 \%$ & $0-5 \%$ & $2.12-2.35 \%$ & $1.85-10.4 \%$ \\
\hline \multirow{6}{*}{$\begin{array}{l}\text { Table } 3 \text {. } \\
\text { The optimal portfolio } \\
\text { compositions based } \\
\text { on nominal } \\
\text { arithmetic mean } \\
\text { returns }\end{array}$} & \multicolumn{9}{|c|}{ Interest-earning deposits not included } \\
\hline & $\mathrm{E}$ & - & $14.44 \%$ & $0.00 \%$ & $0.00 \%$ & $51.06 \%$ & $34.50 \%$ & $1.90 \%$ & $2.47 \%$ \\
\hline & $\mathrm{F}$ & - & $23.44 \%$ & $0.00 \%$ & $0.00 \%$ & $21.45 \%$ & $55.10 \%$ & $2.05 \%$ & $3.44 \%$ \\
\hline & G & - & $45.09 \%$ & $0.00 \%$ & $0.00 \%$ & $0.00 \%$ & $54.91 \%$ & $2.20 \%$ & $4.90 \%$ \\
\hline & $\mathrm{H}$ & - & $100.00 \%$ & $0.00 \%$ & $0.00 \%$ & $0.00 \%$ & $0.00 \%$ & $2.35 \%$ & $10.39 \%$ \\
\hline & Range & - & $14-100 \%$ & $0-0 \%$ & $0-0 \%$ & $0-51 \%$ & $0-55 \%$ & $1.9-2.35 \%$ & $2.47-10.4 \%$ \\
\hline
\end{tabular}

\begin{tabular}{|c|c|c|c|c|c|c|c|c|}
\hline \multirow[b]{2}{*}{ Portfolios } & \multirow[b]{2}{*}{ Rinterest } & \multicolumn{4}{|c|}{ Weighting factors } & \multirow[b]{2}{*}{ RGold } & \multicolumn{2}{|c|}{ Portfolio's } \\
\hline & & RBist100 & RUSD & REuro & RRealEstate & & Expected return & $\mathrm{SD}$ \\
\hline \multicolumn{9}{|c|}{ Interest-earning deposits included } \\
\hline A & $80.96 \%$ & $2.60 \%$ & $5.00 \%$ & $0.00 \%$ & $7.57 \%$ & $3.88 \%$ & $0.43 \%$ & $1.02 \%$ \\
\hline B & $94.52 \%$ & $3.63 \%$ & $0.00 \%$ & $0.00 \%$ & $0.00 \%$ & $1.85 \%$ & $0.50 \%$ & $1.11 \%$ \\
\hline $\mathrm{C}$ & $48.85 \%$ & $51.15 \%$ & $0.00 \%$ & $0.00 \%$ & $0.00 \%$ & $0.00 \%$ & $0.58 \%$ & $5.04 \%$ \\
\hline $\mathrm{D}$ & $0.00 \%$ & $100.00 \%$ & $0.00 \%$ & $0.00 \%$ & $0.00 \%$ & $0.00 \%$ & $0.65 \%$ & $9.81 \%$ \\
\hline Range & $0-95 \%$ & $3-100 \%$ & $0-5 \%$ & $0-0 \%$ & $0-8 \%$ & $0-4 \%$ & $0.43-0.65 \%$ & $1.02-9.81 \%$ \\
\hline \multicolumn{9}{|c|}{ Interest-earning deposits not included } \\
\hline $\mathrm{E}$ & - & $14.32 \%$ & $0.00 \%$ & $0.00 \%$ & $53.08 \%$ & $32.60 \%$ & $0.21 \%$ & $1.92 \%$ \\
\hline $\mathrm{F}$ & - & $23.47 \%$ & $0.00 \%$ & $0.00 \%$ & $23.17 \%$ & $53.36 \%$ & $0.36 \%$ & $2.88 \%$ \\
\hline G & - & $43.33 \%$ & $0.00 \%$ & $0.00 \%$ & $0.00 \%$ & $56.67 \%$ & $0.50 \%$ & $4.24 \%$ \\
\hline $\mathrm{H}$ & - & $100.00 \%$ & $0.00 \%$ & $0.00 \%$ & $0.00 \%$ & $0.00 \%$ & $0.65 \%$ & $9.81 \%$ \\
\hline Range & - & $14-100 \%$ & $0-0 \%$ & $0-0 \%$ & $0-53 \%$ & $0-57 \%$ & $0.21-0.65 \%$ & $1.92-9.81 \%$ \\
\hline
\end{tabular}

Table 4.

The optimal portfolio compositions based on real arithmetic mean returns

\begin{tabular}{|c|c|c|c|c|c|c|c|c|}
\hline \multirow[b]{2}{*}{ Portfolios } & \multirow[b]{2}{*}{ Ninterest } & \multirow[b]{2}{*}{ NBist100 } & \multicolumn{4}{|c|}{ Weighting factors } & \multicolumn{2}{|c|}{ Portfolio's } \\
\hline & & & NUSD & NEuro & NRealEstate & NGold & Expected return & $\mathrm{SD}$ \\
\hline \multicolumn{9}{|c|}{ Interest-earning deposits included } \\
\hline A & $23.73 \%$ & $0.11 \%$ & $0.00 \%$ & $0.00 \%$ & $74.07 \%$ & $2.08 \%$ & $1.77 \%$ & $1.64 \%$ \\
\hline $\mathrm{B}$ & $48.53 \%$ & $0.02 \%$ & $0.00 \%$ & $0.00 \%$ & $48.96 \%$ & $2.49 \%$ & $1.90 \%$ & $1.68 \%$ \\
\hline $\mathrm{C}$ & $73.27 \%$ & $0.00 \%$ & $0.00 \%$ & $0.00 \%$ & $23.79 \%$ & $2.95 \%$ & $2.03 \%$ & $1.78 \%$ \\
\hline $\mathrm{D}$ & $100.0 \%$ & $0.00 \%$ & $0.00 \%$ & $0.00 \%$ & $0.00 \%$ & $0.00 \%$ & $2.17 \%$ & $1.93 \%$ \\
\hline Range & $24-100 \%$ & $0-0 \%$ & $0-0 \%$ & $0-0 \%$ & $0-74 \%$ & $0-3 \%$ & $1.77-2.17 \%$ & $1.64-1.93 \%$ \\
\hline \multicolumn{9}{|c|}{ Interest-earning deposits not included } \\
\hline $\mathrm{E}$ & - & $2.27 \%$ & $0.00 \%$ & $0.00 \%$ & $88.55 \%$ & $9.18 \%$ & $1.67 \%$ & $1.68 \%$ \\
\hline $\mathrm{F}$ & - & $9.19 \%$ & $0.00 \%$ & $0.00 \%$ & $56.53 \%$ & $34.28 \%$ & $1.76 \%$ & $2.30 \%$ \\
\hline G & - & $16.11 \%$ & $0.00 \%$ & $0.00 \%$ & $24.51 \%$ & $59.37 \%$ & $1.85 \%$ & $3.32 \%$ \\
\hline $\mathrm{H}$ & - & $0.00 \%$ & $0.00 \%$ & $0.00 \%$ & $0.00 \%$ & $100.00 \%$ & $1.95 \%$ & $5.21 \%$ \\
\hline Range & - & $0-16 \%$ & $0-0 \%$ & $0-0 \%$ & $0-89 \%$ & $9-100 \%$ & $1.67-1.95 \%$ & $1.68-5.21 \%$ \\
\hline
\end{tabular}

Table 5.

The optimal portfolio compositions based on nominal geometric $\mathrm{H}$ mean returns
Inte

$\mathrm{H}$ g deposits not included
$-\quad 14.44 \%$

$-23.44 \%-0.00 \%-0.00 \%$

$100.00 \% \quad 0.00 \% \quad 0.00 \%$

\section{$\mathrm{D}$}

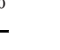




\begin{tabular}{|c|c|c|c|c|c|c|c|c|c|}
\hline \multirow[b]{2}{*}{ Portfolios } & \multirow[b]{2}{*}{ Rinterest } & \multirow[b]{2}{*}{ RBist100 } & \multicolumn{3}{|c|}{ Weighting factors } & \multirow[b]{2}{*}{ RGold } & \multicolumn{2}{|c|}{ Portfolio's } & \multirow{3}{*}{$\begin{array}{l}\text { Role of real } \\
\text { estate and gold } \\
\text { as inflation } \\
\text { hedges }\end{array}$} \\
\hline & & & RUSD & REuro & RRealEstate & & Expected return & SD & \\
\hline \multicolumn{9}{|c|}{ Interest-earning deposits included } & \\
\hline A & $26.95 \%$ & $2.97 \%$ & $11.13 \%$ & $0.00 \%$ & $58.96 \%$ & $0.00 \%$ & $0.10 \%$ & $1.11 \%$ & \\
\hline B & $50.44 \%$ & $2.70 \%$ & $8.47 \%$ & 0.00 & & 1.4 & & $1.02 \%$ & \\
\hline $\mathrm{C}$ & 73 & 2.44 & 5.67 & 0.00 & 14.9 & 3.1 & $0.36 \%$ & & \\
\hline D & $100.00 \%$ & $0.00 \%$ & $0.00 \%$ & $0.00 \%$ & $0.00 \%$ & 0.00 & $0.49 \%$ & $1.12 \%$ & 40 \\
\hline Range & $27-100 \%$ & $0-3 \%$ & $0-11 \%$ & $0-0 \%$ & $0-59 \%$ & $0-3 \%$ & $0.1-0.49 \%$ & $1.01-1.12 \%$ & \\
\hline \multicolumn{9}{|c|}{ Interest-earning deposits not included } & \multirow{6}{*}{$\begin{array}{r}\text { Table } 6 . \\
\text { The optimal portfolio } \\
\text { compositions based } \\
\text { on real geometric } \\
\text { mean returns }\end{array}$} \\
\hline $\mathrm{E}$ & - & $4.21 \%$ & $2.74 \%$ & $0.00 \%$ & $83.87 \%$ & & & & \\
\hline $\mathrm{F}$ & - & 10.49 & 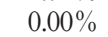 & 0.00 & 56.1 & 33.4 & 0.10 & $1.83 \%$ & \\
\hline G & - & $17.51 \%$ & $0.00 \%$ & $0.00 \%$ & $24.06 \%$ & $58.43 \%$ & $0.19 \%$ & $2.83 \%$ & \\
\hline $\mathrm{H}$ & - & & & & & & & & \\
\hline Range & - & $0-18 \%$ & $0-3 \%$ & $0-0 \%$ & $0-84 \%$ & $9-100 \%$ & $0-0.28 \%$ & $1.29-4.84 \%$ & \\
\hline
\end{tabular}
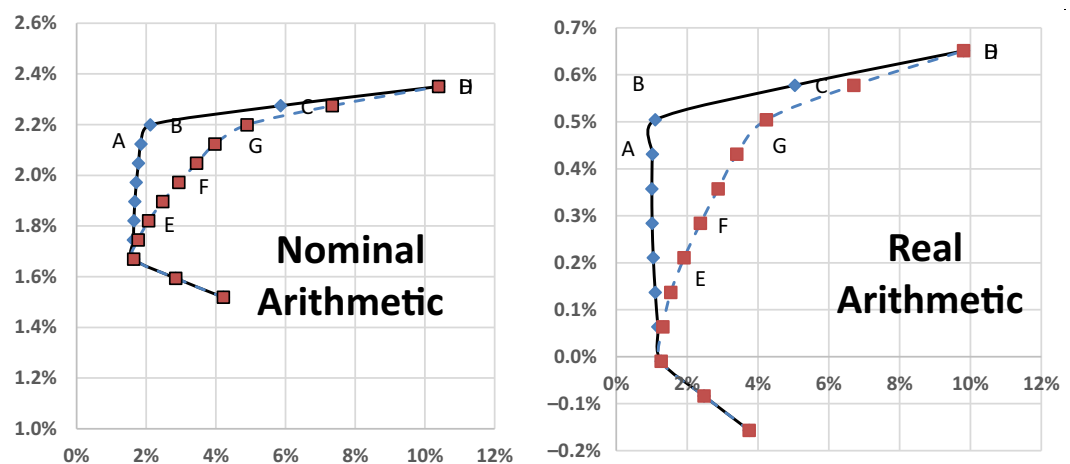

Figure 5.

Efficient Frontiers based on nominal and real arithmetic mean returns
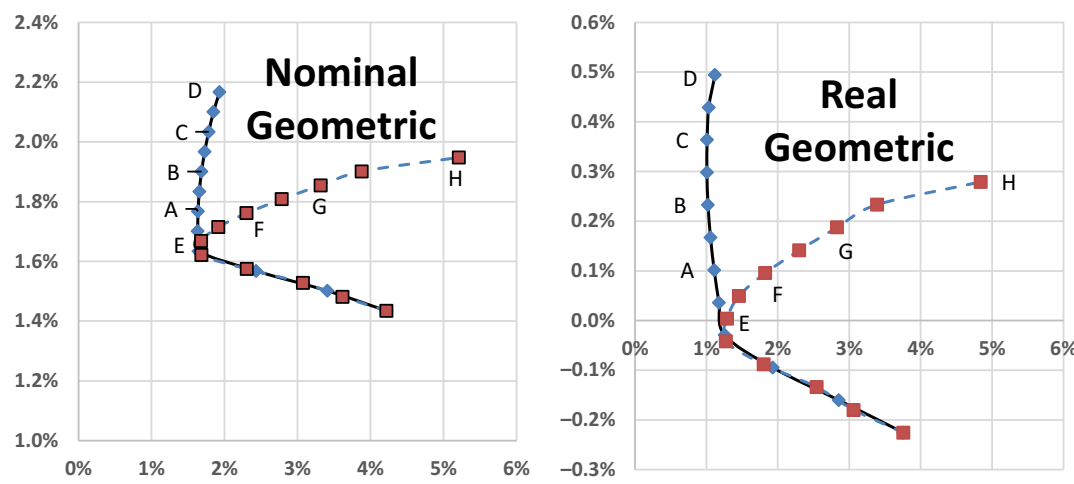

Figure 6. Efficient Frontiers based on nominal and real geometric mean returns 
IMEFM

14,2

404

\subsection{Efficient frontiers based on nominal and real arithmetic mean returns}

Our findings based on the arithmetic mean returns are presented in Tables 3 and 4. Respectively, the two tables show optimal portfolio compositions calculated by using nominal and real arithmetic mean returns. In each table, the portfolios $\mathrm{A}, \mathrm{B}, \mathrm{C}, \mathrm{D}$ were calculated by assuming that interest-earning assets were a viable investment instrument, and the portfolios E, F, G, H were calculated by assuming otherwise.

As can be seen, the portfolio compositions calculated by using the nominal and real arithmetic mean returns are similar. The influence of interest-earning deposits on portfolio compositions is dramatic. When they are included, about $90 \%$ of savings are invested in interest-earning deposits and the stock index. The combined portfolio share of real estate and gold holdings is in the $0 \%-$ $16 \%$ range. When interest-earning deposits are not included, their combined portfolio share becomes much higher: In the two portfolios marked with E, about 85\%; in the two portfolios marked with $\mathrm{F}$, about $76 \%$; in the two portfolios marked with $\mathrm{G}$, about $55 \%$.

Figure 5 below presents our results on diagrams. For ease of comparison, the optimal portfolios in Tables 3 and 4 are shown with markers. On the diagrams, the efficient frontiers roughly (not precisely) correspond to the line segments A-D and E-H. The fact that the exterior efficient frontiers lie above the interior efficient frontiers shows that for an investor, refraining from interest income comes at the cost of lower expected returns.

\subsection{Efficient frontiers based on nominal and real geometric means}

Our findings based on the geometric mean returns are presented in Tables 5 and 6 . Respectively, the two tables show optimal portfolio compositions calculated by using nominal and real geometric mean returns. In each table, the portfolios A, B, C, D were calculated by assuming that interest-earning assets were a viable investment instrument, and the portfolios E, F, G, H were calculated by assuming otherwise.

As can be seen, the portfolio compositions calculated by using the nominal and real geometric mean returns are fairly similar. The influence of interest-earning deposits on portfolio compositions is dramatic. When they are included, their share in the optimal portfolios is substantial, ranging from $23 \%-27 \%$ in the two portfolios marked with A, up to $100 \%$ in the two portfolios marked with D. When not included, the gap left by them is filled to a large extent by real estate and gold: their combined portfolio share increases from $59 \%-$ $76 \%$ up to $93 \%-98 \%$ when we compare portfolios marked with A and E; from $38 \%-52 \%$ up to $89 \%-91 \%$ when we compare portfolios marked with B and F; and from $18 \%-27 \%$ up to $82 \%-84 \%$ when we compare portfolios marked with $\mathrm{E}$ and $\mathrm{G}$.

Figure 6 below presents our results on diagrams. For ease of comparison, the optimal portfolios in Tables 5 and 6 are shown with markers. On the diagrams, the efficient frontiers roughly (not precisely) correspond to the line segments A-D and E-H. The fact that the exterior efficient frontiers lie above the interior efficient frontiers shows that for an investor, refraining from interest income comes at the cost of lower expected returns.

\section{Summary}

In this paper, we studied the role played by real estate and gold as inflation hedges. What spurred our study was the strong household demand for real estate and gold in Turkey in the past two decades. We hypothesized that this strong demand might have been caused by the combined influence of Islam and Turkey's high and volatile rates of inflation.

It is a widely held belief that in Islam, earning interest on money is prohibited. Therefore, many Turks exclude interest-earning assets from their investment portfolios. However, when the rate of inflation is high and volatile, an interest-earning asset is the best instrument to shield savings from inflationary depreciation and volatility. Their exclusion 
from an investment portfolio may amplify the roles of real estate and gold as inflation hedges. We argued that this situation might be the underlying factor for the unusually strong demand for real estate and gold in Turkey.

We tested our hypothesis using Markowitz's mean-variance model. We calculated optimal investment portfolios when the portfolio includes interest-earning deposits, and when it does not. Our findings provided evidence in support of our hypothesis: we found that the share of portfolio holdings of real estate and gold increase substantially if the portfolio does not include an interest-earning asset. For ease of reference, Table 7 below shows the optimal portfolio compositions for medium-return and medium-risk portfolios calculated using four sets of data: nominal and real arithmetic mean returns; nominal and real geometric mean returns. (These portfolios correspond to portfolios $\mathrm{C}$ and $\mathrm{G}$ in Tables $3,4,5,6$.) For instance, when we look at the findings calculated using real geometric mean returns, we see that: When interest-earning deposits are removed, the shares of portfolio real estate and gold holdings increase from $14.97 \%$ to $24.06 \%$ and $3.16 \%$ to $58.43 \%$, respectively.

Note that in this paper, we provide indirect evidence on the influence of religiosity on people's investment choices. As a possible line of future research, our hypothesis can be tested at the microlevel. If one has access to individual-level data on people's religiosity and their investment choices, a direct relationship between them can be found (if there is one) through a causality analysis. Furthermore, it will be useful if, in future studies, researchers examine the influence of aversion to interest income on investment portfolios in the context of other Muslim-majority countries.

\section{Policy recommendations}

Turkey is a fast-emerging economy, with its remarkable $4.5 \%$ annual growth rate in the past 20 years. However, the country has a low savings rate, and it relies heavily on foreign capital for growth. Therefore, to foster growth, the country's limited savings must be channeled into productive uses. To curtail the chronic current account deficits, domestic savings must be channeled into investment projects in export-oriented industries. However, Turkish households use much of their savings to purchase real estate and gold. This situation prevents the country from realizing its full growth potential. Our analysis suggests that the strong demand for real estate and gold in Turkey is partly caused by conservative households' aversion to interest income. Under rampant inflation, interest-earning assets are the best shield against inflationary depreciation and volatility. The fact that religious Turks avoid these assets amplifies the role of real estate and gold as inflation hedges in their investment portfolios. This fuels the demand for real estate and gold in the country. To tame this effect, the country's rate of inflation must be lowered and stabilized.

\begin{tabular}{|c|c|c|c|c|c|c|c|c|c|}
\hline \multirow[b]{2}{*}{ Portfolio } & \multirow[b]{2}{*}{ Interest } & \multirow[b]{2}{*}{ Bist100 } & \multicolumn{2}{|c|}{ Weighting factors } & \multirow[b]{2}{*}{ Real estate } & \multirow{2}{*}{ Gold } & \multicolumn{2}{|c|}{ Portfolio's } & \\
\hline & & & USD & Euro & & & Expected return & $\mathrm{SD}$ & \\
\hline \multicolumn{10}{|c|}{ Interest-earning deposits included:portfolios marked with C } \\
\hline N-Arithmetic & $45.75 \%$ & $54.25 \%$ & $0.00 \%$ & $0.00 \%$ & $0.00 \%$ & $0.00 \%$ & $2.27 \%$ & $5.86 \%$ & \\
\hline R-Arithmetic & $48.85 \%$ & $51.15 \%$ & $0.00 \%$ & $0.00 \%$ & $0.00 \%$ & $0.00 \%$ & $0.58 \%$ & $5.04 \%$ & \\
\hline N-Geometric & $73.27 \%$ & $0.00 \%$ & $0.00 \%$ & $0.00 \%$ & $23.79 \%$ & $2.95 \%$ & $2.03 \%$ & $1.78 \%$ & \\
\hline R-Geometric & $73.76 \%$ & $2.44 \%$ & $5.67 \%$ & $0.00 \%$ & $14.97 \%$ & $3.16 \%$ & $0.36 \%$ & $1.01 \%$ & Table 7. \\
\hline \multicolumn{9}{|c|}{ Interest-earning deposits not included:portfolios marked with $G$} & The optimal portfolio \\
\hline N-Arithmetic & - & $45.09 \%$ & $0.00 \%$ & $0.00 \%$ & $0.00 \%$ & $54.91 \%$ & $2.20 \%$ & $4.90 \%$ & compositions for \\
\hline R-Arithmetic & - & $43.33 \%$ & $0.00 \%$ & $0.00 \%$ & $0.00 \%$ & $56.67 \%$ & $0.50 \%$ & $4.24 \%$ & medium-return, \\
\hline N-Geometric & - & $16.11 \%$ & $0.00 \%$ & $0.00 \%$ & $24.51 \%$ & $59.37 \%$ & $1.85 \%$ & $3.32 \%$ & medium-risk \\
\hline R-Geometric & - & $17.51 \%$ & $0.00 \%$ & $0.00 \%$ & $24.06 \%$ & $58.43 \%$ & $0.19 \%$ & $2.83 \%$ & portfolios \\
\hline
\end{tabular}

Role of real estate and gold as inflation hedges

405

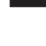


IMEFM

14,2

Furthermore, the conservative savings must be lured into the financial system, and to this end, Turkey's growing Islamic banking industry can play a crucial role. However, in Turkey, many conservatives are suspicious of whether Islamic banking services are compliant with Islamic tenets. Therefore, learning from the experiences of countries that have a larger Islamic banking industry (for instance, the United Arab Emirates and Malaysia) can provide policymakers useful guidelines.

\section{Note}

1. Alcohol consumption is banned in Islam. While annual per capita alcohol consumption (15+) is $6.4 \mathrm{~L}$ in the globe and $9.8 \mathrm{~L}$ in Europe, in Turkey the corresponding figure is only $2 \mathrm{~L}$ (WHO, 2020). Even the 2 L figure may be an overstatement of Turkish people's alcohol use since much of alcohol demand in Turkey is caused by the country's vast tourism industry.

\section{References}

Ahmed, S. and Cardinale, M. (2005), "Does inflation matter for equity returns?", Journal of Asset Management, Vol. 6 No. 4, pp. 259-273.

Aktürk, H. (2016), "Do stock returns provide a good hedge against inflation? An empirical assessment using Turkish data during periods of structural change", International Review of Economics and Finance, Vol. 45, pp. 230-246.

Alagidede, P. and Panagiotidis, T. (2010), "Can common stocks provide a hedge against inflation? Evidence from African countries”, Review of Financial Economics, Vol. 19 No. 3, pp. 91-100.

Algaoud, L.M. and Lewis, M.K. (2007), "Islamic critique of conventional financing", Handbook of Islamic Banking, Edward Elgar, Northampton, Vol. 38.

Amenc, N., Martellini, L. and Ziemann, V. (2009), "Inflation-hedging properties of real assets and implications for asset-liability management decisions", The Journal of Portfolio Management, Vol. 35 No. 4, pp. 94-110.

Arnold, S. and Auer, B.R. (2015), "What do scientists know about inflation hedging?", The North American Journal of Economics and Finance, Vol. 34, pp. 187-214.

Azad, A.S.M.S., Azmat, S., Chazi, A. and Ahsan, A. (2018), "Can Islamic banks have their own benchmark?”, Emerging Markets Review, Vol. 35, pp. 120-136.

Barry, C.B. and Rodriguez, M. (2004), "Risk and return characteristics of property indices in emerging markets”, Emerging Markets Review, Vol. 5 No. 2, pp. 131-159.

Batten, J.A., Ciner, C. and Lucey, B.M. (2014), "On the economic determinants of the gold-inflation relation", Resources Policy, Vol. 41, pp. 101-108.

Baur, D.G. and McDermott, T.K. (2010), "Is gold a safe haven? International evidence", Journal of Banking and Finance, Vol. 34 No. 8, pp. 1886-1898.

Beckmann, J. and Czudaj, R. (2013), "Gold as an inflation hedge in a time-varying coefficient framework", The North American Journal of Economics and Finance, Vol. 24 No. 1, pp. 208-222.

Bekaert, G. and Wang, X. (2010), "Inflation risk and the inflation risk premium", Economic Policy, Vol. 25 No. 64 , pp. $755-806$.

Bodie, Z. (1976), "Common stocks as a hedge against inflation”, The Journal of Finance, Vol. 31 No. 2, pp. $459-470$.

Bruno, S. and Chincarini, L. (2010), "A historical examination of optimal real return portfolios for nonUS investors”, Review of Financial Economics, Vol. 19 No. 4, pp. 161-178.

Callot, L.A.F., Kock, A.B. and Medeiros, M.C. (2017), "Modeling and forecasting large realized covariance matrices and portfolio choice", Journal of Applied Econometrics, Vol. 32 No. 1, pp. 140-158. 
Caporale, G.M. and Sousa, R.M. (2016), "Consumption, wealth, stock and housing returns: evidence from emerging markets", Research in International Business and Finance, Vol. 36, pp. 562-578.

Ceritoğlu, E. (2017), "The effect of house price changes on cohort consumption in Turkey", Central Bank Review, Vol. 17 No. 3, pp. 99-110.

Chong, B.S. and Liu, M.-H. (2009), "Islamic banking: interest-free or interest-based?", Pacific-Basin Finance Journal, Vol. 17 No. 1, pp. 125-144.

Christou, C., Gupta, R., Nyakabawo, W. and Wohar, M.E. (2018), "Do house prices hedge inflation in the US? A quantile cointegration approach", International Review of Economics and Finance, Vol. 54, pp. 15-26.

Estrada, J. (2010), “Geometric mean maximization: an overlooked portfolio approach?”, The Journal of Investing, Vol. 19 No. 4, pp. 134-147.

Fama, E.F. and Schwert, G.W. (1977), “Asset returns and inflation”, Journal of Financial Economics, Vol. 5 No. 2, pp. 115-146.

Fama, E.F. (1981), "Stock returns, real activity, inflation, and money", The American Economic Review, Vol. 71 No. 4, pp. 545-565.

Fischer, S. (1982), "Seigniorage and the case for a national money", Journal of Political Economy, Vol. 90 No. 2, pp. 295-313.

Fisher, I. (1930), “The theory of interest the Macmillan company”, New York.

Geske, R. and Roll, R. (1983), "The fiscal and monetary linkage between stock returns and inflation", The Journal of Finance, Vol. 38 No. 1, pp. 1-33.

Gulseven, O. (2018), "Estimating factors for the demand of organic milk in Turkey", British Food Journal, Vol. 120 No. 9, pp. 2005-2016.

Gülseven, O. and Ekici, Ö. (2016), "The Turkish appetite for gold: an Islamic explanation”, Resources Policy, Vol. 48, pp. 41-49.

Gultekin, N.B. (1983), "Stock market returns and inflation: evidence from other countries", The Journal of Finance, Vol. 38 No. 1, pp. 49-65.

Hasanov, F. and Dacy, D.C. (2009), "Yet another view on why a home is one's castle", Real Estate Economics, Vol. 37 No. 1, pp. 23-41.

Hassan, K. and Lewis, M. (2009), Handbook of Islamic Banking, Edward Elgar Publishing.

Jaffe, J.F. and Mandelker, G. (1976), "The 'fisher effect' for risky assets: an empirical investigation", The Journal of Finance, Vol. 31 No. 2, pp. 447-458.

Kaul, G. (1987), "Stock returns and inflation: the role of the monetary sector", Journal of Financial Economics, Vol. 18 No. 2, pp. 253-276.

Khan, F. (2010), "How 'Islamic' is Islamic banking?”, Journal of Economic Behavior and Organization, Vol. 76 No. 3, pp. 805-820.

Kim, J.H. and Ryoo, H.H. (2011), "Common stocks as a hedge against inflation: evidence from centurylong US data”, Economics Letters, Vol. 113 No. 2, pp. 168-171.

Konda Araştırma ve Danışmanlık (2007), "Gündelik Hayatta Din, Laiklik ve Türban Araştırması”, available at: https://konda.com.tr/wp-content/uploads/2017/02/2007_09GündelikHayattaDin LaiklikTürban.pdf

Konda Araştırma ve Danışmanlık (2018), "What has changed in 10 years?", available at: https:// interaktif.konda.com.tr/en/landing.php (accessed 28 August 2018).

Kothari, S.P. and Shanken, J. (2004), "Asset allocation with inflation-protected bonds", Financial Analysts Journal, Vol. 60 No. 1, pp. 54-70.

Larsen, A.B. and Mcqueen, G.R. (1995), "REITs, real estate, and inflation: lessons from the gold market", The Journal of Real Estate Finance and Economics, Vol. 10 No. 3, pp. 285-297.

Lewis, M.K. and Algaoud, L.M. (2001), Islamic Banking Books, Edward Elgar Publishing.

Lintner, J. (1975), “Inflation and security returns”, The Journal of Finance, Vol. 30 No. 2, pp. 259-280. 
IMEFM

14,2

Loistl, O. (2015), "Does mean-variance portfolio management deserve expected utility's approximative affirmation?", European Journal of Operational Research, Vol. 247 No. 2.

Loughran, T. and Ritter, J.R. (2002), "Why has IPO underpricing changed over time?”, SSRN Electronic Journal, Vol. 33 No. 3, pp. 5-37.

Luintel, K.B. and Paudyal, K. (2006), “Are common stocks a hedge against inflation?”, Journal of Financial Research, Vol. 29 No. 1, pp. 1-19.

Markowitz, H. (1952), "Portfolio selection”, The Journal of Finance, Vol. 7 No. 1, pp. 77-91.

Nelson, C.R. (1976), "Inflation and rates of return on common stocks", The Journal of Finance, Vol. 31 No. 2, pp. 471-483.

Ozkan, F., Ozkan, O. and Gunduz, M. (2012), "Causal relationship between construction investment policy and economic growth in Turkey", Technological Forecasting and Social Change, Vol. 79 No. 2, pp. 362-370.

Reboredo, J.C. and Rivera-Castro, M.A. (2014), "Can gold hedge and preserve value when the US dollar depreciates?”, Economic Modelling, Vol. 39, pp. 168-173.

Soytas, U., Sari, R., Hammoudeh, S. and Hacihasanoglu, E. (2009), "World oil prices, precious metal prices and macroeconomy in Turkey”, Energy Policy, Vol. 37 No. 12, pp. 5557-5566.

Stix, H. (2013), "Why do people save in cash? Distrust, memories of banking crises, weak institutions and dollarization", Journal of Banking and Finance, Vol. 37 No. 11, pp. 4087-4106.

Swinkels, L. (2012), "Emerging market inflation-linked bonds", Financial Analysts Journal, Vol. 68 No. 5, pp. 38-56.

Tursoy, T. and Faisal, F. (2018), "The impact of gold and crude oil prices on stock market in Turkey: empirical evidences from ARDL bounds test and combined cointegration", Resources Policy, Vol. 55, pp. 49-54.

Vieira, F.A.C., Holland, M. and Resende, M.F. (2012), "Financial dollarization and systemic risks: new empirical evidence", Journal of International Money and Finance, Vol. 31 No. 6, pp. 1695-1714.

Wen, X. and Cheng, H. (2018), "Which is the safe haven for emerging stock markets, gold or the US dollar?", Emerging Markets Review, Vol. 35, pp. 69-90.

WHO (2020), "GHO | world health statistics data visualizations dashboard | harmful use of alcohol", World Health Organization, available at: https://apps.who.int/gho/data/node.sdg.3-5-viz?lang= en (accessed 27 August 2019).

Zhang, Y., Li, X. and Guo, S. (2017), "Portfolio selection problems with Markowitz's mean-variance framework: a review of literature", Fuzzy Optimization and Decision Making, Vol. 17 No. 2, pp. 1-34.

\section{Further reading}

Garcia, J.A. and van Rixtel, A.A. (2007), "Inflation-linked bonds from a Central bank perspective", ECB Occasional Paper, No. 62.

\section{Corresponding author}

Osman Gulseven can be contacted at: osmangulseven@hotmail.com

For instructions on how to order reprints of this article, please visit our website: 